* Corresponding author

E-mail address:bodane.rita@rkk.uni-obuda.hu (Bodáné Kendrovics Rita)

Article information

Article history: AMS-Volume16-No.1-00154-12

Received 4 December 2011

Accepted 15 January 2012

\section{Results of Project Pedagogy at Environmental Engineerig Education of Óbuda University}

\author{
Rita Bodáné Kendrovics Ph.D.
}

Óbuda University, Rejtö Sándor Faculty of Light Industry and Environmental Protection Engineering Institute of Environmental Engineering, Hungary

\section{KEY WORDS}

Environmental engineering education, environmental education, environmental awareness, responsible attitude, environmental attitude

\section{ABSTRACT}

The objective of environmental engineering BSc education is to develop competences like complex system approach, problem recognition and resolution, lifelong learning and responsible attitude for the environment in addition to high level scientific knowledge. To achieve this goal, besides professional academic training, environment education needs to be implemented, where project pedagogy -as the strategy of environment pedagogy-can be efficiently applied. The study aims to prove the effectiveness of project education in terms of professional knowledge as well as in environmental attitudes by the results of project "Load of impurities in low water streams" validated by two-group environmental pedagogy experiment. Based on the results it can be stated, that project pedagogy can be well integrated with traditional pedagogical methods and may become their efficient supplement in environmental engineering BSc education.

\section{Introduction}

The objective of environmental engineering BSc education is to establish and develop competences like complex system approach, problem recognition and resolution, lifelong learning and responsible attitude for the environment in addition to develop high level theoretical scientific knowledge.

Experiences gathered since the new system has started show, that students' performance and their attitude to the professional courses taken are not efficient enough in this form of education. They are not motivated to learn due to the lack of direct experiences, their need for self-controlled learning is not geared. Students can't see coherencies between different subjects and they are not able to apply what they have learned. Their system-based approach is not adequate and the scope is not enough for developing general and professional competences. The current Environmental Engineering BSc education provides high level theoretical scientific knowledge, but it's not appropriate enough to develop competences laid down in directives and requirements of the education. By fragmenting content of ecological and engineering subjects to different courses, ecological approach can't be ensured. Students can acquire decision making and responsibility skills, but it assumes teaching and learning based 
on personal experiences.

In the first semester of year 2011/2012, we started a two-group environmental-pedagogy experiment with the aim to confirm that we can develop missing competences through project pedagogy methods, beside high level theoretical scientific education.

Project education is a special, open educational strategy focusing on problems and aims at solving complex problems from real life through activityorientation. Methods, techniques and materials used enlarge the school frame and provide natural learning environment. [1] Achieving success motivate students to set and reach additional goals. This way self-controlled learning skills evolve, students can formulate their personal goals, learn how to work to achieve these goals, and because of success - as a positive feedback - they can set further goals and motivate themselves. [2]

In the course of project education, students work for a goal, which is appealing and interesting for them. They can choose their partners and work with a flexible schedule. They don't have to meet external requirements, so learning based on personal motivation is a natural consequence. Solving problems motivates students to know more about their topic and they can prepare their products. Learning process is not a pressure, learning is not an obligation, it is a tool for reaching their goals. [3] The project "Load of impurities in low water streams" would like to demonstrate the results achievable by project education in Water quality protection course of Environmental Engineering BSc.

\section{Water quality protection project: “Load of impurities in low water streams"}

This project for environmental engineering students is needed, because:

- Water qualification of Low water streams in Hungary is incomplete; many streams remained without qualification since the launch of WFD.

- During their higher level studies, students should acquire routine in water qualification, it being a basic competence of this profession.

- Exploring the pollution of streams require field trips, and wide knowledge about the catchment area.

- Knowledge of the measuring principles does not mean that students can apply them.
Natural scientific learning methods (experiments, observation, measure) do not or minimally appear in the education.

- Engineers' society do not have an ecological view, despite that sustainability requires that. Engineers are thinking in a short time effects while working out technologies, but processes are longer in the environment.

Location of the project: Óbuda University (ÓE), Rejtő Sándor Faculty of Light Industry and Environmental Protection Engineering (RKK)

Field exercise location: Aranyhegyi-stream and its catchment area, Solymár and Pilisvörösvár Wastewater Cleaning Plant

Target audience: ÓE RKK Environmental Engineering BSC, second and third grade.

Number of the whole group: 17 students

Duration of the project: 14 educational weeks (one semester)

The problem to be solved by the project group members was the level of pollution in our low water streams and their inadequate quality. Project goal was to explore the basin of the Aranyhegyistream and assess the factors influencing quality of the low water stream. During the project work, students worked in four smaller groups (Table 1), that were setup on the first class with the help of a notional map.

Students could choose module groups based on their personal interest, and then they formulated the problems to be solved. In their work, great emphasis was put on tasks aiming at appropriate water utilization, re-utilization of water and protection of water ecosystems, helping this way to develop environmental awareness, ecological approach and responsible behaviour for the environment.

The output (product) of the project was a water quality map of Aranyhegyi-stream, taking into consideration the expectations of the WFD and established a pattern to qualify other low water streams. Students collected data and information during the project period and analysed them. The project leader teacher gave a list of literature to the students; this was the first step to collect information from. Students were looking for further literature within their topics and analysed them too. They did biological, physical and chemical tests, which were necessary for the qualification. They appointed test holes during field inspection.

Students discovered coherency of causes and ef- 
fects based on their tests' results and direct experiences in the environment. They could formulate how problems of water pollution should have been solved. Groups worked independently, they fulfilled tasks and decided responsibly. They prepared a written report together, which contained specifications of the catchment area; pollution sources influencing the quality of the stream with exact coordinates (waste-water cleaning plants, agricultural areas, settlement, rainwater duct, illegal waste deposition, etc.); descriptions of measurements; and their independent researches. They present- ed this summary at the end of the project. In addition to this summary, they made many various and valuable output materials. They made some records of measurements, articles and a poster for the World Water Day which motivates for sustainable water management. Students made a macro invertebrate cyclopaedia, that can facilitate testing macro invertebrates of Aranyhegyi-stream in the future. They made a cyclopaedia of plants to help testing macro vegetation and a creative machinery measuring water discharge.

Table 1: Final collecting table $[P / R / A=$ variables $]$

Load of impurities in low water streams

I. Living water - Natural water ecosystem

(5 students)

Exploration of the catchment area

Ecological water qualification through testing macro invertebrates

Ecological water qualification through testing macro vegetation
II. Function of waste-water in water quality (5 students)

Formation and contents of waste-water

Waste-water cleaning

Effects of cleaned waste-water on receivers
III. Effects of agricultural activity on water quality (3 students)

Environmental pollution effect of animal husbandry

Effects of crop production that endanger water quality

Ecological husbandry Precipitation husbandry

IV. Effects of urbanisation processes (4 students)

Processes and effects of urbanisation

Effects of bed-directing
In the planning, organisational and construction period we used the following pedagogical methods:

\section{- Methods in the planning period helping to dis- cover personal goals:}

- Thinking aloud, maps of concepts, conversation, heuristic conversation, disputation, explanation

- Methods during organisational period facilitating independency, creativity and research:

- Observation, collection, analysis, planning

- Methods in the construction period to facilitate independency, creativity, research and cooperation:

- Observation, measurement, collection, analysis, testing, data processing, systematization, interviews, field work, product, case study, project method, field trip.

Presentation and assessment at the end of the project was very important, because students got feedback of their work. The presentation was a team work, in front of the other teams and an invited jury. After the presentations each team evaluated their own and other team's (modules) works, while the jury evaluated the whole project and wok of the module teams too.

Portfolios and independent works of students were good for evaluating personal achievements within the project. The greatest advantage of the evaluation of independent work is that the learning process and the way to achieve the goal become visible for both the student and the teacher. [4] Portfolios contain plans, drafts, tasks and selfevaluation forms of the students. Making this portfolio helps developing self-evaluation skills, self-reflection and meta-cognition during learning process.

During "Load of impurities in low water streams" project we used many activity-oriented methods in addition to traditional methods (e.g. lectures, explanation, etc.). By enlarging the learning place field work ensured an active, constructive learning space in contrast to passive learning [5], which is very important in environmental engineering education. There are a lot of expectations towards graduated environmental engineers, and we can teach these skills in this kind of learning process. 
Results of the questionnaire we made and the selfevaluating sheets of the students can show us the efficiency of the project.

\section{Efficiency of project education in developing comperences, two-group attitude surve}

In our two-group environmental pedagogy experiment, project method was the independent variable, while the dependent variables were the changed knowledge and skills.

At the beginning of the semester second-grade students taking up Water quality protection course and third-grade students taking up Technologies of waste-water cleaning course were given an opportunity to be a member of the project. Joining was voluntary, and members did not get credits for the project, because it was just an extra-curricular experimental course. Students could take up project course in their free time. We chose 17 students (the course was oversubscribed) for the project group. These students were not obliged to visit practical lessons of Water quality protection course, but they had to listen lectures. The Technologies of waste-water cleaning course contains only lectures, that is why students from the project group had to listen them, and at the end of the semester they had to pass the exam normally.

This is how we made the two groups; first is the project group with 17 members, who visited lectures and the project instead of practical lessons; and the second group with 25 members, who visited lectures once a week and practical lessons twice (normal process).

I made a survey at the beginning and at the end of the semester too in both groups. I analysed how dependent variables have changed during the semester.

I used a written questionnaire and answers from students' self-evaluation sheets. In this way I could analyse students' environmental attitude, participation in work, intensity, and efficiency of the method.

Before the survey I made these hypotheses:

- Environmental responsibility and ecological thinking of the project group will change significantly in a positive way against the control group

- Project group's environmental attitude will change in a positive way too

- Responsibility of the project group will increase and they will be more informed.

\subsection{Method of the survey}

We used a socio psychological survey, that is used for measuring global environmental attitude. It was made by Dunlop and Van Lier, it's name is New Ecological Paradigm (NEP). [6] It contains 15 statements (Table 2) that examine the effect of hu-

Table 2: Questions (made by Dunlop and Van Lier) for the emotional part of environmental attitude (1: Totally false, 2: Mostly false 3: Do not know 4: Mostly agree, 5: Totally agree, true)

\begin{tabular}{|c|c|c|c|c|c|}
\hline 1. Because of the increase of the population, we are going to reach Earth's keeping capacity. & 1 & 2 & 3 & 4 & 5 \\
\hline 2. People have rights to change the natural environment for needs to be satisfied. & 1 & 2 & 3 & 4 & 5 \\
\hline 3. If people change the environmental processes, it may produce fatal consequences. & 1 & 2 & 3 & 4 & 5 \\
\hline 4. Human ingenuity ensures that Earth will not become unliveable. & 1 & 2 & 3 & 4 & 5 \\
\hline 5. People destroy the environment irresponsibly. & 1 & 2 & 3 & 4 & 5 \\
\hline 6. The Earth has plenty of natural resources; we only should learn how to exploit them. & 1 & 2 & 3 & 4 & 5 \\
\hline 7. Plants and animals have the same rights to life as people have. & 1 & 2 & 3 & 4 & \\
\hline $\begin{array}{l}\text { 8. The balance of the nature is strong enough to overcome the effects of developed industrial } \\
\text { societies. }\end{array}$ & 1 & 2 & 3 & 4 & \\
\hline 9. Despite of our special abilities, we are subordinated to the laws of the nature. & 1 & 2 & 3 & 4 & \\
\hline 10. The so-called "ecological crisis" we must face, is an exaggeration. & 1 & 2 & 3 & 4 & \\
\hline 11. The Earth is like a spaceship, where we have finite number of space and resources. & 1 & 2 & 3 & 4 & \\
\hline 12. People are destined to reign over the nature. & 1 & 2 & 3 & 4 & \\
\hline 13. The balance of the nature is very sensitive and can easily capsize. & 1 & 2 & 3 & 4 & \\
\hline 14. People must know processes of the nature to control them. & 1 & 2 & 3 & 4 & \\
\hline 15. If everything continues as before, we will reach a big Ecological disaster very soon. & 1 & 2 & 3 & 4 & \\
\hline
\end{tabular}


manity to the biosphere, in 5 independent factors. It examines the emotional part of environmental attitude, maximum 75 points.

Two parts of environmental attitude: emotional and behavioral attitude are not always in line with each other, as we can see in other analysis too. A survey made by Attila Varga in eco- and not ecoschools [7] and an attitude survey made by Angéla Perényiné Somogyi [8] in adult population and children population show that emotional attitude is more positive than behavioral attitude. During environmental education it is very important that students can learn some options for actions; and be able to use them too (e.g. during the project, students observed their water consumption).

By answering the questions referring to behavioral attitude (Table 3) maximum 60 points can be reached.

Table 3: Questions of measuring behavioral attitude in environmental attitude (1: Totally false, 2: Mostly false 3: Do not know 4: Mostly agree, 5: Totally agree, true).

\begin{tabular}{|c|c|c|c|c|c|}
\hline 1. News of environmental pollution are made me upset. & 1 & 2 & 3 & 4 & 5 \\
\hline 2. I am worried about shrinking water resources of the Earth & 1 & 2 & 3 & 4 & 5 \\
\hline 3. I would like to use (or maybe I use) renewable energy resources in my household. & 1 & 2 & 3 & 4 & 5 \\
\hline 4. I warn the others when they pollute the environment. & 1 & 2 & 3 & 4 & 5 \\
\hline 5. I am not worried about the purity of drinking water. & 1 & 2 & 3 & 4 & 5 \\
\hline 6. I am aware of the environmental footprint of products I buy. & 1 & 2 & 3 & 4 & 5 \\
\hline 7. I like to bath in bath tub. & 1 & 2 & 3 & 4 & 5 \\
\hline 8. I often hike in the nature. & 1 & 2 & 3 & 4 & 5 \\
\hline 9. I wash the dishes in running water. & 1 & 2 & 3 & 4 & 5 \\
\hline 10. I like to pay more for "green", environmentally friendly products. & 1 & 2 & 3 & 4 & 5 \\
\hline 11. I am worried about people do not take care of the environment enough. & 1 & 2 & 3 & 4 & 5 \\
\hline 12. I usually take part in village/city cleaning days. & 1 & 2 & 3 & 4 & 5 \\
\hline
\end{tabular}

My survey contained 10 questions (opened and closed questions too) and they were directed to sustainable use of water and environmental awareness. I made this survey twice with the same groups (project group and control group); first was at the beginning of the project, on the 12th of September, 2011; second was after the project, on the 15th of February, 2012.

\section{Results of the survey}

I tried to guess what students think about serious global and local problems with the first and the second question of the questionnaire (1: What do you think, what are the most serious problems of humanity? 2: What do you think, what are the most serious (environmental) problems in Hungary?).

Answers of the members of the project group showed us, that after project work they could accurately formulate problems and raised several new aspects. At the beginning of the semester the greatest problems were: global warming, great use of notrenewable resources ("hunger for energy") and lack of drinking water. In the second time, most of the students wrote overpopulation and lack of drinking water. New aspects appeared too: e.g. lack of information and environmental awareness, irresponsible use of lands, "people think they are almighty", urbanization. These are problems that students faced during the project.

For the question of problems in Hungary, at the first time most students wrote air pollution and the problem of waste deposit, the lack of use of alternative resources, and problems of water pollution. At the second time, they rather wrote deposit and collection of waste and illegal deposition, the second most written aspect was air pollution. A new aspect appeared here too: environmental awareness, lack of responsibility and wasteful lifestyle.

At the first time most of the members of the control group wrote global warming as the most serious environmental problem of humanity, and wasting of not-renewable resources.

In the answers we found overpopulation, poverty, famine, pollution and waste of fresh water, the lack 
of environmental education, irresponsibility and the lack of environmental awareness too. At the second time most of the students wrote overpopulation, global warming, water pollution and waste of fresh water.

Environmental problems in Hungary by the view of the control group are the un-sustainable waste management, e.g. the lack of selective waste collection, and illegal waste disposition causing environment pollution, followed by the pollution of natural water and air pollution. At the second time the most common problem was about waste too, but new aspects appeared also: flood, inland inundation, drought and pollution of rivers. National problems are wasting lifestyle and smog too.

Answers of the project group and control group were not too different, but it was perceptible that during the project, members of the project group became more informed, and they approach had changed. At the end of the project they could accurately formulate global and local problems and they could isolate these problems too.

I used a statistic program, called SPSS 11.5 to analyse the rest of the questions. First step was an analysis of significance to find out if there was a significant difference of environmental attitude between the project and control group at the beginning of the project. Second step was a repeated analysis of significance based on the answers given at the end of the project. Applied tests: ANOVA test, t-test and paired t-test.

Objective of question 3 of the questionnaire (Do you know how much water you use daily? Possible answers: Yes, exactly; More or less; No, I have never counted it; No I am not interested in) was to see changes in water usage habits during the project.

At the beginning of the semester, difference between the two group was not significant $(p=0,209)$ - we can say significance if $p$ is lower than $0,05^{1}$. By the end of the semester it changed, members of the project group started to pay attention how much water they use daily (Figure 1).

We made a paired t-test on the answers of this water usage question, the result shows a positive change in environmental awareness and water usage habits by the project members, at the end of the semester they paid more attention to their water usage.

We made an ANOVA-test on the answers of question 4 of the questionnaire (How do you strive to re- duce waste in your household? I avoid of purchasing over packed products, I use sustained shopping bag, I avoid of purchasing mineral water and soft drinks packed in PET, I compress PET, I try to recycle, I collect waste separately, I do nothing). It showed, that at the beginning of the project, there was no significant difference in waste reduction between the two groups, but by the end of the project it became significant ${ }^{2}$ (Figure 2). The result of the paired t-test proved that environmental attitude of students taking part in the project had positively changed, the importance of waste reduction had been increased.

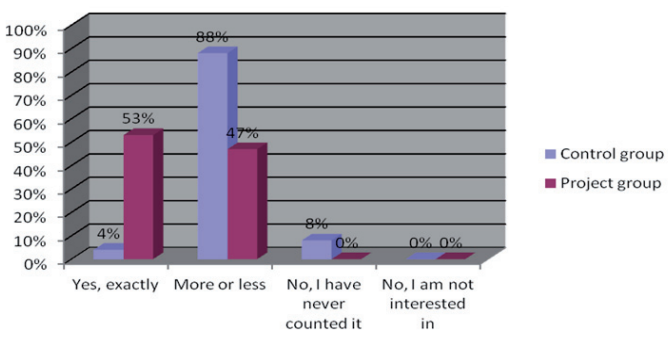

Fig. 1: Change in water usage at the second time, at the end of the semester.

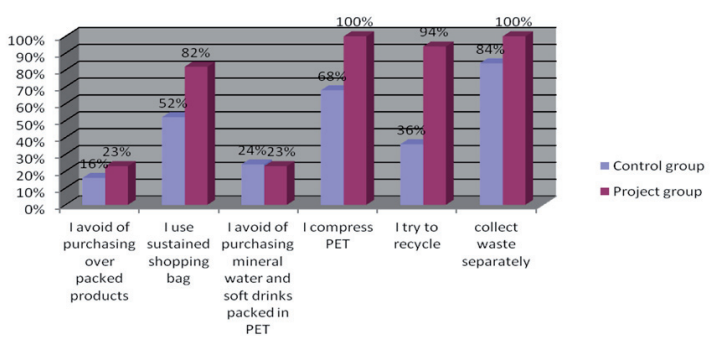

Fig. 2: Difference between the two groups int he question of waste reduction at the end of the semester.

The analysis of question 5 of the questionnaire (Do you understand the meaning of conscious water usage - gray water, domestic waste water, etc? Yes, totally; Roughly, but it is enough; Partly, but I should be more informed; No, I have never thought about it) also shows that the project has a positive effect to environmental awareness. The results of the ANOVA shows at the beginning of the project, that difference between the two group was not significant $(p=0,742)$, but at the end of the project it was $^{3}$ (Figure 3).

Paired t-test of conscious water usage also shows, that by the end of the semester project group members' attitude had significantly changed ${ }^{4}$. 
Answers given to question 6 (How do you economize water? - I do not economize; I pay attention to water usage during teeth brushing, shower, etc.; I use water-saving equipment; I collect rain water; Other, e.g.:..) do not show significant ${ }^{5}$ difference between the two groups at the beginning of the semester, but it became significant ${ }^{6}$ by the end of it (Figure 4).

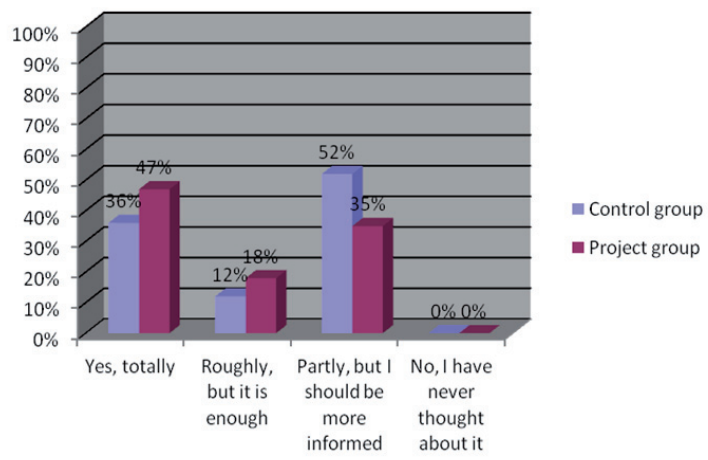

Fig. 3: Conscious water usage answers show significant difference between the two groups at the end of the semester.

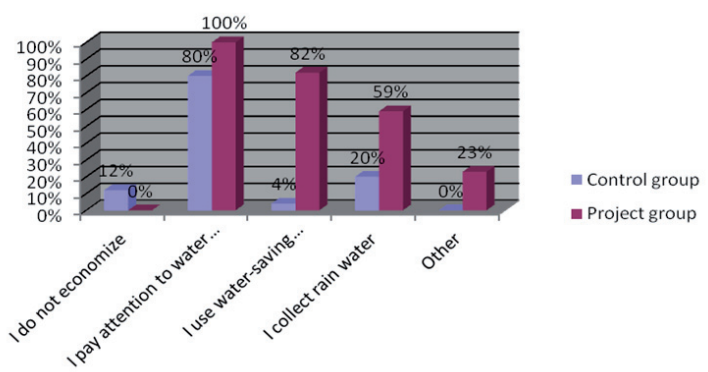

Fig. 4: The difference between the two groups at the end of the semester in water economization question.

Paired t-test also verified the change in the project group's attitude?.

I presented 4 variables in the previous section that all prove success of the project, moreover it had a positive effect to its members. Now, I show a new global variable, called environmental awareness index. This index is formed and standardized from the 4 earlier variables. At the beginning of the project, groups were similar to each other ${ }^{8}$. But at the end of the project I observed significant difference?. Moreover $63,3 \%$ of heterogeneity of the environmental awareness can be explained by taking part in the project. Time comparison presents that project had a significantly positive effect to environmental awareness ${ }^{10}$. These results clearly demonstrate the efficiency of project method in environmental edu- cation.

Answers given to question 7 (What are the most important points in shopping for you?) in the second survey show clearly that during project work the shopping habit of project members changed, instead of "value for money", environmentally friendly point came to the first place (Figure 5).

By question 8 of the questionnaire (Please, list some web sites and journals, related to environmental protection, that you know) I wanted to know how well-informed students were and how much they read. My hypothesis was, that students read very few professional literature and they were not very well-informed. They don't have enough information about everyday happenings in the environment. They are not motivated enough, that is why I thought, that during project work their informational level would be increased. When I analysed the answers, I considered 4 aspects: student got 0 if he/ she did not write anything; $1-2$ if he/she wrote at least one but maximum 2 web sites/journals; 3-4 if he/she wrote at least 3 but maximum 4 web sites/ journals; and 5 if he/she wrote 5 or more than 5 .

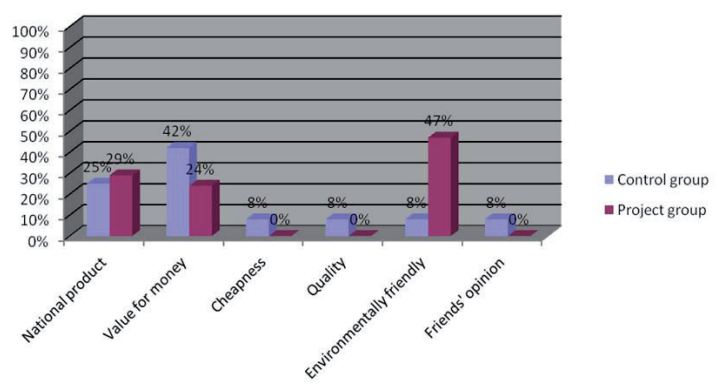

Fig. 5: Difference between project and control group at the end of the semester in shopping habits question

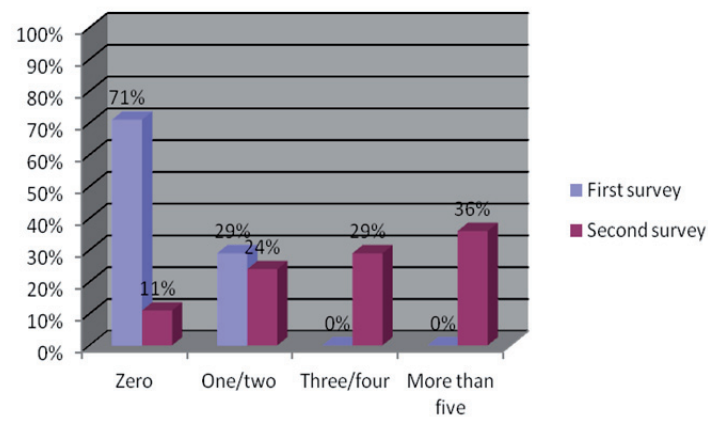

Fig. 6: Journals and websites known by the members of the project group in the first and second survey. 
This test proves that within the project group informational level has positively and significantly" changed (Figure 6), but within control group it has not changed at all12.

Results show that by the end of the semester members of the project group became better informed, they knew more websites and journals.

Question 9 of the questionnaire (Table 2) was about the emotional part of environmental attitude. I calculated mean of answers to NEP (1 to 5 points each). Maximum points were 75 , because each statement (15) could get 5 points maximum. Higher score means more positive environmental attitude of the student.

Within project group the average was 51 points at the beginning of the semester, by the end of the semester it increased a little bit (Figure 7). All surveys within both groups showed positive environmental attitude, since the neutral environmental attitude's points were 36 in the scale of NEP. [7] Within the control group environmental attitude points were positive, but did not present any change, both at the beginning and at the end of the semester they were 51 points.

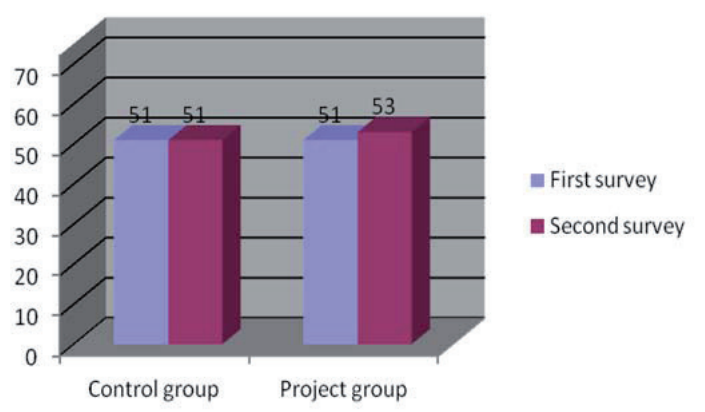

Fig. 7: Mean points of environmental attitude within control and project group in the first and second survey too

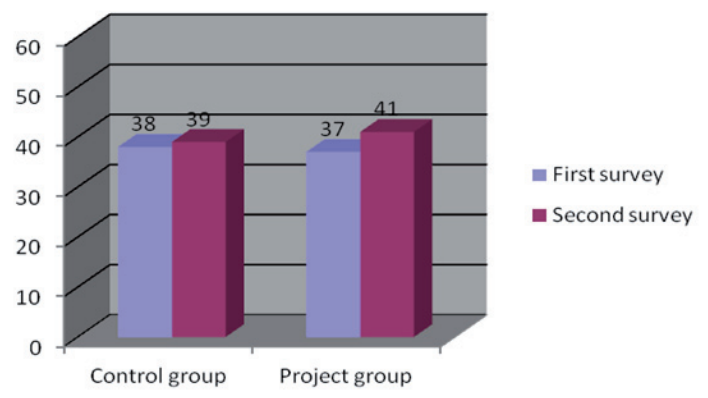

Fig. 8: Mean points of behavioral environmental attitude within control and project group in the first and second survey too
In the project group this 2-point difference with a paired t-test was not significant ${ }^{13}$.

In the project group this 2-point difference with a paired t-test was not significant ${ }^{14}$.

Question 10 of the questionnaire (last) was about behavioral environmental attitude (Table 3). I distinguished two dimensions: 1) thinking and opinions of the environment ${ }^{15}$ and 2 ) activity for the environment. $^{16}$ I took 5 variables to the thinking/opinion dimension, maximum points were 25 . I took 7 variables to the activity dimension, maximum points were 35. Maximum points were altogether 60.

Paired t-test proved that project had a positively significant effect to its members (at the beginning it was 37 points but to the end it increased to 41 points) ${ }^{\mathbf{1 7}}$. Within the control group there was no significant change in points ${ }^{18}$ (Figure 8). Results of the two-dimension test in thinking/opinion dimension did not show any significant change, so project did not change the thinking about the environment. ${ }^{19}$ All the four surveys' (project group before and after the project, control group before and after the project) mean points were 18 , which is $72 \%$ of the maximum 25 points. Environmental attitude points (in the previous section) showed positive change within the project group, so I could expect that the behavioral environmental attitude had also changed positively. Paired t-test verified the positive effect of the project within behavioral environmental attitude points, because at the beginning their mean was 20 points, and by the end it increased to 23 points. ${ }^{20}$ This is a prominent result -taking into account the facts proven by the previous tests, that emotional environmental attitude is more positive, than behavioral one-, because the project increased the members' behavioral environmental attitude points too.

${ }^{1}$ It means: responsibility level is $95 \%\left({ }^{*}\right)$, Type I risk is $5 \%$. The significance of the relationship can be $\left(^{* *}\right)$ - $99 \%$ responsibility or $\left(^{* * *}\right)-99,9 \%$ responsibility. Significance of the test is $\left(^{* *}\right)$ if $p<0,01$; and $\left(^{* *}\right)$ if $p<0,001$

${ }^{2} 1$ : at the beginning: $p=0,242$ (not significant), 2 : at the end of the project: $p=0,000$ - significant with

$\left.{ }^{* * *}\right)$ responsibility

${ }^{3} \mathrm{P}=0,033\left(^{*}\right)$ responsibility

${ }^{4} p=0,000\left({ }^{* *}\right)$ responsibility

${ }^{5} \mathrm{P}=0,351$ (not significant)

${ }^{6} p=0,000\left({ }^{* * *}\right)$ responsibility 
${ }^{7} \mathrm{P}=0,006\left({ }^{* *}\right)$ responsibility

${ }^{8} \mathrm{P}=0,191$ (not significant)

${ }^{9} p=0,000\left({ }^{* * *}\right)$ responsibility

${ }^{10} p=0,001\left(^{* * *}\right)$ responsibility

$\left.{ }^{11} p=0,001{ }^{* * *}\right)$ responsibility

${ }^{12} \mathrm{p}=0,575$ (do not significant)

${ }^{13} \mathrm{p}=0,259$ (not significant)

${ }^{14} \mathrm{p}=0,259$ (not significant)

${ }^{15}$ | list the following statements here:

- News of environmental pollution are made me upset.

- I am worried about shrinking water resources of the Earth

- I am not worried about the purity of drinking water.

- I am aware of the environmental footprint of products I buy.

- I am worried about people do not take care of the environmentenough.

${ }^{16}$ I list the following statements here:

- I would like to use (or maybe I use) renewable energy resources in my household.

- I warn the others when they pollute the environment.

- I like to bath in bath tub.

- I often hike in the nature.

- I wash the dishes in running water.

- I like to pay more for "green", environmentally friendly products.

- I usually take part in village/city cleaning days.

${ }^{17} \mathrm{P}=0,012\left(^{*}\right)$ responsibility

${ }^{18} \mathrm{P}=0,578$ (not significant)

${ }^{19}$ Project group: $P=0,136$ (not significant)

Control group: $p=0,752$ (not significant)

${ }^{\mathbf{2 0}} \mathrm{p}=0,022\left(^{*}\right)$ responsibility

\section{Summary, Conclusions}

Environmental attitude test with questionnaire proved the positive effects of the project method in environmental education. Hypotheses set at the beginning of the semester got validated. During the project there was a positive change in environmental behavior and responsibility towards the environment too. Statistics showed that there were more positive changes in the behavioral dimension of the environmental attitude, than in the emotional dimension. Results acknowledged, that the project method reached its goal; members became more environmentally friendly in their everyday lives.

All in all, I can say that the project developed required skills set in the directives and requirements of the education. Moreover end term exams of students proved that their knowledge has also grown significantly. Project method integrated in the environmental engineering education strategy, by supplementing its high level academic qualification, can be a suggested method in environmental engineering BSc education.

\section{References}

[1] KOVÁTS-NÉMETH Mária: Az erdőpedagógiától a környezetpedagógiáig, Comenius Kft., Pécs, 2010. 206. p.

[2] RÉTHY Endréné: Motiváció és az önszabályozó tanulás In: (Réthy Endréné szerk.): A tanítás-tanulás hatékony szervezése. Adalékok a jó gyakorlat pedagógiai alapjaihoz, Educatio KHT, Bp., 2008. 63-76. p.

[3] FALUS Iván: Az oktatás stratégiái és módszerei In: (Falus Iván szerk.): Didaktika, Nemzeti Tankönyvkiadó, Bp., 2003. 280. p.

[4] RADNÓTI Katalin: Milyen oktatási módszereket alkalmaznak a pedagógusok a mai magyar iskolában in: (Kerber Zoltán szerk.): Híd a tantárgyak között Országos Közoktatási Intézet, Bp., 2006. 135. p.

[5] NÉMETHNÉ KATONA Judit: A környezet- és természetvédelmi oktatás terepi lehetőségeinek alkalmazása és módszereinek továbbfejlesztése a Máriaremetei-szurdokvölgy példáján Doktori (PhD) értekezés NyME Kitaibel Pál Környezettudományi Doktori Iskola, témavezető: Dr. Berki Imre egyetemi docens, Sopron, 2006. 37. p.

[6] DUNLOP, R. E.- VAN LIER, K. D. - MERTIG, A. G. - JONES, R. E.: Measuring Endorsement of the New Ecological Paradigm: A Revised NEP Scale, Journal of Social Issues Vol. 56, No. 3, 2000. 432-433. p.

[7] VARGA Attila: A környezeti nevelés pedagógiai, pszichológiai alapjai, Doktori PhD disszertáció, Eötvös Loránd Tudományegyetem Bölcsészettudományi Kar Neveléstudományi Doktori Iskola, Konzulens: Nahalka István, Budapest, 2004. 70. p., 69. p.

[8] PERÉNYINÉ SOMOGYI Angéla: A fenntarthatóság ökológiai, pedagógiai és pszichológiai vonatkozásai, Nyugat-magyarországi Egyetem Erdőmérnöki Kar Kitaibel Pál Környezettudományi Doktori Iskola Környezetpedagógia (K3) Program Doktori (PhD) értekezés, Témavezető: Kovátsné Dr. habil Németh Mária főiskolai tanár, Sopron, 2011. 71. p., 174. p. 


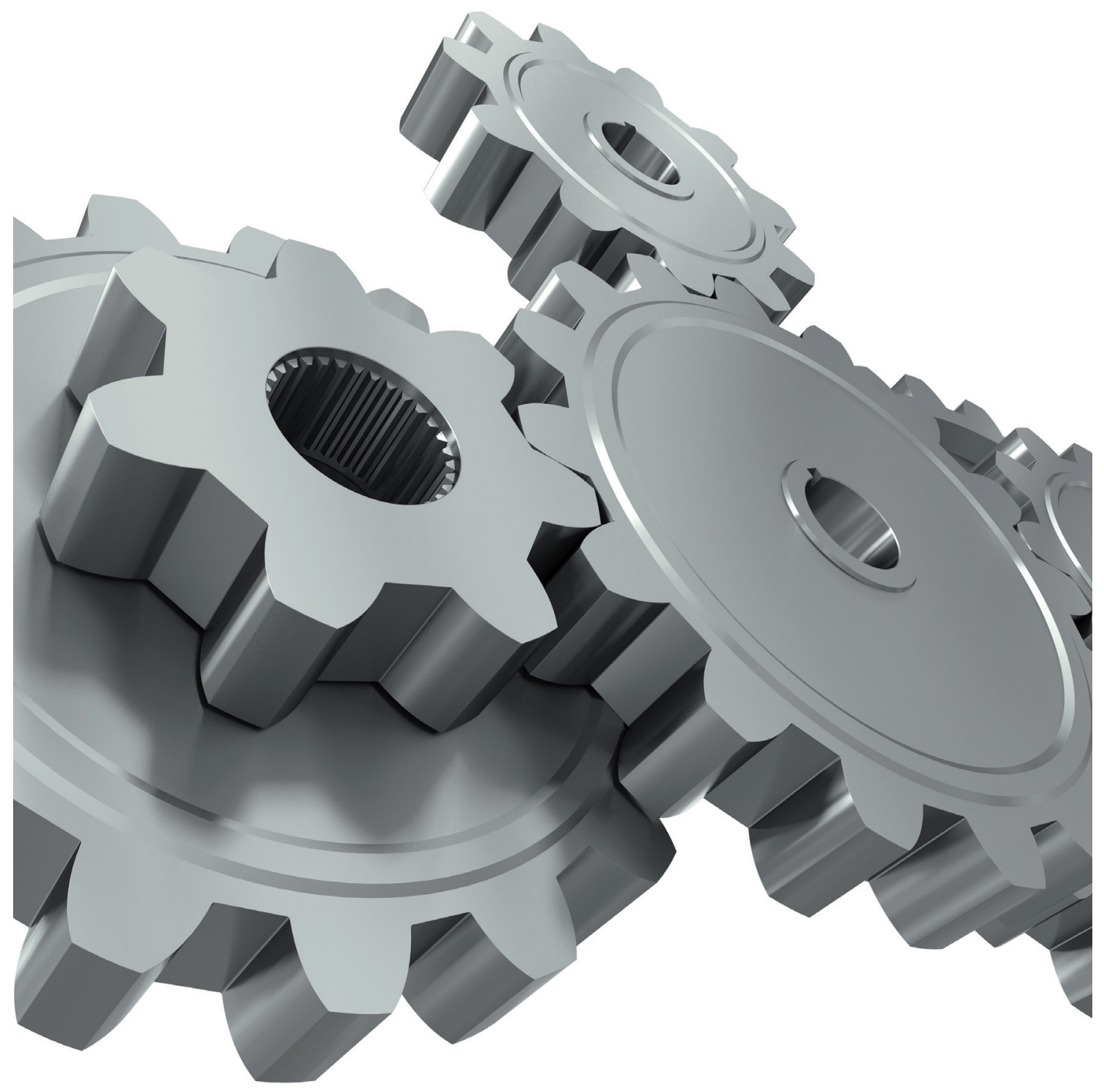

